\title{
Transformasi Gelombang Swell dan Gelombang Angin di Perairan Selatan Bali
}

\author{
FITRI SUCIATY \\ Jurusan Teknik Sipil, Institut Teknologi Nasional \\ Email: suciaty.fitri@gmail.com
}

\begin{abstract}
ABSTRAK
Gelombang swell dengan energi yang besar dan dapat menjalar hingga ratusan kilometer dari daerah pembangkitannya diketahui berpotensi merusak struktur pantai dan juga dapat mengganggu segala aktivitas yang dilakukan di pantai. Gelombang swell juga dinyatakan memberikan pengaruh yang besar pada inundasi yang terjadi di sepanjang pantai selatan Jawa dan Bali pada tanggal 4-9 Juni 2006 (Nugraheni, dkk., 2017). Studi transformasi gelombang swell dan gelombang angin di perairan selatan Bali dilakukan dengan pemodelan numerik gelombang menggunakan model gelombang generasi ketiga SWAN model. Simulasi dilakukan dengan tiga nested grid dengan resolusi grid \#1, \#2 dan \#3; masing-masing sebesar 0.050, 0.005, dan $0.001^{\circ}$. Simulasi dilakukan untuk dua buah skema pemodelan, yaitu model gelombang swell dan model gelombang angin. Hasil model menunjukan kesesuaian dengan data pengamatan. Hasil simulasi memperlihatkan gelombang swell yang berasal dari Samudera Hindia mendominasi kondisi gelombang di perairan selatan Bali selama periode simulasi (18 Desember 2011-6 Februari 2012). Dibandingkan dengan gelombang angin, gelombang swell menghasilkan tinggi gelombang yang lebih besar baik di lepas pantai maupun di area dekat pantai. Gelombang swell mengalami refraksi yang kuat di sekitar Bukit Peninsula.
\end{abstract}

Kata kunci: gelombang Swell, gelombang angin, pemodelan transformasi gelombang.

\begin{abstract}
ABSTRACK
Swells with its large energy can propagate up to hundreds of kilometers from the generation location. Therefore, swells have the potential to damage the structure of the coast and also can disrupt all activities carried out on the coast. Swells were also stated to have a major influence on the inundation that occurred along the southern coast of Java and Bali on June 4 to 9, 2006 (Nugraheni, et al., 2017). The study of swells and wind waves transformations in the waters of southern Bali is carried out by numerical wave modeling using a third generationwave model SWAN model. Nested grids are used with spatial resolution of grid \#1, \#2 and \#3; is $0.05^{\circ}, 0.005^{\circ}$, and $0.001^{\circ}$, respectively. Simulations are carried out for two modeling schemes that areswell models and wind wave models. The simulation shows compliance with observation data. The result shows swells originating from the Indian Ocean mostly dominated wave conditions in the waters of southern Bali during simulation period (18 Desember 2011-6 Februari 2012). Compared to wind waves, swells produce higher wave both in offshore and coastal area. Swells experienced a strong refraction around the Bukit Peninsula.
\end{abstract}

Keywords: swell, wind wave, wave transformation model. 


\section{PENDAHULUAN}

Gelombang merupakan fenomena alam yang sangat penting yang terjadi pada batas muka laut dan udara. Gelombang laut dengan periode 1 detik sampai dengan 30 detik dikenal sebagai gelombang gravitasi. Terdapat dua jenis gelombang gravitasi, yaitu gelombang angin dan gelombang swell. Gelombang angin sering disebut sebagai young waves, yaitu gelombang yang dibangkitkan dan dipengaruhi oleh angin lokal. Angin yang kencang dan mempunyai arah yang tetap menyebabkan terbentuknya gelombang angin (windsea) yang kemudian berkembang menjadi fully developed sea atau gelombang swell (Habibie, dkk., 2013). Gelombang swell kemudian menjalar pada jarak yang sangat jauh dari daerah pembentukannya dengan sedikit pembelokan arah (Young, 1999). Maka gelombang swell dapat dikatakan sebagai gelombang angin yang karena energinya yang sangat besar maka akan terlepas dari daerah pembentukannya (Habibie, 2013).

Kajian mengenai gelombang swell menjadi penting untuk dilakukan karena gelombang ini berpotensi merusak struktur pantai dan aktivitas lain yang terjadi di wilayah pantai (Mettlach et al., 1994). Simulasi gelombang swell yang dilakukan oleh Habibie, dkk. (2013), menunjukan pada tanggal 17-19 Mei 2007, kecepatan angin yang mencapai $22 \mathrm{~m} / \mathrm{s}$ di selatan Afrika membangkitkan gelombang swell yang melintasi Samudera Hindia. Gelombang swell ini kemudian menjalar ke utara menyusuri pantai barat Sumatra menuju Aceh dan ke timur menyusuri pantai selatan Jawa menuju Bali dan Nusa Tenggara. Gelombang tersebut akan mengalami efek pendangkalan (shoaling) yang berpengaruh terhadap kenaikan tinggi gelombang (wave setup) di pantai, sehingga dapat menimbulkan inundasi dan kerusakan infrastruktur. Analisis gelombang dan swell yang dilakukan oleh Nugraheni, dkk. (2017) menunjukan bahwa gelombang swell memberikan pengaruh yang sangat besar terhadap inundasi yang terjadi pada tanggal 4-9 Juni 2006 di sepanjang pantai selatan Jawa dan Bali. Gelombang ekstrim yang terjadi merupakan superposisi dari gelombang pasang surut, anomali tinggi muka air, dan gelombang angin dan swell yang tinggi. Choi, et al. (2003), menyatakan bahwa gelombang laut akan bertambah tinggi antara 0.5-1 meter di Laut Kuning ketika terjadi superposisi antara gelombang badai bersamaan dengan adanya gelombang pasang surut.

Penelitian ini bertujuan untuk mengetahui kondisi gelombang laut yang dihasilkan dari penjalaran gelombang swell dengan periode panjang dan gelombang angin dengan periode yang lebih pendek di perairan selatan Bali, dimana hal tersebut merupakan salah satu faktor yang sangat penting dalam perencanaan struktur pantai dan juga usaha perlindungan pantai.

Kajian mengenai gelombang laut yang gaya pembangkitnya angin selalu mengasumsikan kondisi ideal tanpa adanya gelombang swell, terutama untuk observasi di lapangan. Pada observasi di lapangan, gelombang angin dan gelombang swell yang memiliki dinamika yang berbeda, sulit untuk dipisahkan. Oleh karena itu, kajian transformasi gelombang swell dan gelombang angin pada studi ini dilakukan dengan menggunakan pemodelan gelombang generasi ketiga, dimana gelombang swel/yang merupakan gelombang nonlinier dihitung secara eksplisit, sehingga 
gelombang swell dan gelombang angin dapat dipisahkan. Pemodelan transformasi gelombang pada studi ini dilakukan dengan menggunakan SWAN Model.

\section{PEMODELAN TRANSFORMASI GELOMBANG}

\subsection{Persamaan Pembangun dan Perhitungan Numerik Model Gelombang SWAN}

Kajian gelombang swell dan gelombang angin pada studi ini dilakukan dengan memodelkan transformasi gelombang dengan menggunakan Model SWAN versi 41.20 yang dikembangkan oleh Booij et al., (1999). SWAN merupakan pemodelan numerik gelombang generasi ketiga yang dapat digunakan untuk mensimulasikan gelombang di daerah pantai, danau, ataupun estuari dengan menggunakan persamaan dasar kesetimbangan aksi (action balance) antara sources dan sink (Booij et al., 1999). Formulasi persamaan pembangun yang digunakan pada model SWAN, yaitu persamaan kesetimbangan aksi, dapat dilihat pada Persamaan 1 dan Persamaan 2. Suku sources dan sink, $S_{\text {tot, }}$ terdiri dari input angin, interaksi nonlinear gelombang, dan suku disipasi yang terdiri dari disipasi akibat whitecapping, gesekan dasar, dan akibat gelombang pecah, seperti terlihat pada Persamaan 3.

$$
\begin{gathered}
N(\sigma, \theta)=\frac{E(\omega, \theta)}{\sigma} \\
\frac{\partial}{\partial t} N+\frac{\partial}{\partial x} c_{x} N+\frac{\partial}{\partial y} c_{y} N+\frac{\partial}{\partial \sigma} c_{\sigma} N+\frac{\partial}{\partial \theta} c_{\theta} N=\frac{S_{t o t}}{\sigma}
\end{gathered}
$$

dimana,

$\frac{\partial}{\partial t} N \quad$ : perubahan densitas aksi terhadap waktu,

$\frac{\partial}{\partial x} c_{x} N$ : penjalaran energi gelombang dalam ruang $x$,

$\frac{\partial}{\partial y} c_{y} N$ : penjalaran energi gelombang dalam ruang $y$,

$\frac{\partial}{\partial \sigma} c_{\sigma} N$ : pergeseran frekuensi karena variasi kedalaman,

$\frac{\partial}{\partial \theta} c_{\theta} N$ : refraksi akibat variasi kedalaman,

$c_{x}, c_{y} \quad$ : kecepatan propagasi energi di ruang geografis (spasial $x$ dan $y$ ),

$c_{\sigma}, c_{\theta} \quad$ : kecepatan propagasi energi diruang spektral dan ruang,

$S_{\text {tot }} \quad$ : suku source dan sink yang menunjukan proses fisis pembangkitan oleh angin, disipasi energi, dan redistribusi energi.

$$
S_{\text {total }}=S_{i n}+S_{n l}+S_{d s, w}+S_{d s, b}+S_{d s, b r}
$$

dimana,

$S_{\text {in }} \quad$ : input angin,

$S_{n l} \quad$ : interaksi nonlinear gelombang,

$S_{d s, w}$ : disipasi akibat whitecapping,

$S_{d s, b}$ : disipasi akibat gesekan dasar,

$S_{d s, b r}$ : disipasi akibat gelombang pecah. 


\subsection{Desain Model}

Simulasi dilakukan dengan metode nested grid untuk efisiensi hasil model serta untuk mendapatkan hasil model yang akurat dengan resolusi tinggi. Area nested grid ditunjukan oleh Gambar 1 dan Gambar 2. Tabel 1 menunjukan rincian untuk masing-masing nested grid.

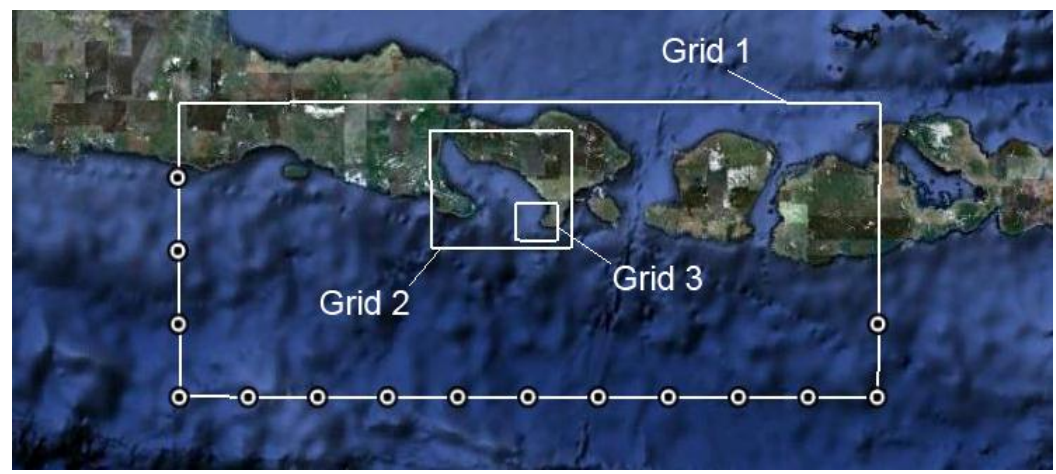

Gambar 1. Struktur nested grid dari tiga grid model transformasi gelombang. Lingkaran pada grid luar menunjukkan lokasi dimana data gelombang lepas pantai dimasukkan pada batas model.

Tabel 1. Spesifikasi Grid Model SWAN.

\begin{tabular}{ccccc}
\hline Grid & Garis Bujur & Lintang & Resolusi & Ukuran \\
\hline \#1 & $112.5 \mathrm{BT}-117.5 \mathrm{BT}$ & 10LS-8LS & $0.05^{\circ}$ & $101 \times 41 \mathrm{cel} / \mathrm{s}$ \\
\hline \#2 & $114.3 \mathrm{BT}-115.3 \mathrm{BT}$ & 9LS-8.2LS & $0.005^{\circ}$ & $201 \times 161 \mathrm{cel} / \mathrm{s}$ \\
\hline \#3 & $114.9 \mathrm{BT}-115.2 \mathrm{BT}$ & $\mathbf{8 . 9 5 \mathrm { LS } - 8 . 7 \mathrm { LS }}$ & $0.001^{\circ}$ & $301 \times 251 \mathrm{cells}$ \\
\hline
\end{tabular}
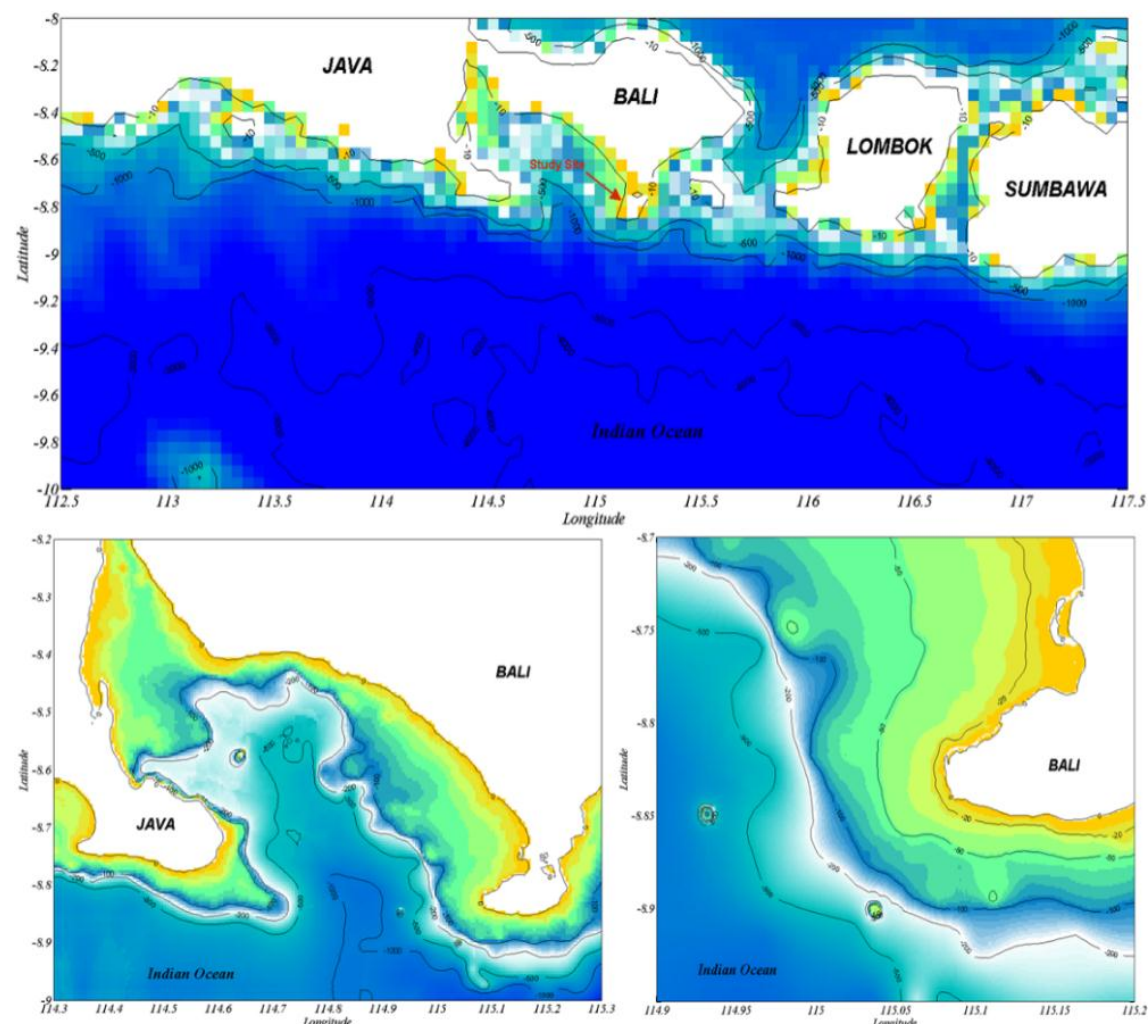

Gambar 2. Grid model SWAN, grid luar \#1 (atas), tengah \#2 (kiri bawah) dan lokasi \#3 (kanan bawah). 
Daerah studi diketahui dipengaruhi oleh gelombang swell dengan periode panjang yang berasal dari belahan bumi selatan dan juga gelombang lokal yang terbentuk oleh angin. Model dirancang dengan mempertimbangkan kedua kondisi tersebut. Simulasi dilakukan untuk dua buah skema pemodelan yang berbeda, yaitu: model gelombang swell saat musim tenggara/musim kering dan (2) model gelombang angin saat musim hujan.

Untuk simulasi gelombang swell, data hindcast gelombang model WAVEWATCH III (Tolman, 2009) yang diekstrak di lokasi di sepanjang tepi grid terluar digunakan sebagai input kondisi batas untuk model SWAN. Data yang digunakan yaitu data pada tahun 2010, karena data pada tahun tersebut dianggap dapat mewakili kondisi gelombang yang diamati selama 14 tahun dari data hindcast. Statistik joint probability untuk tiga titik di sepanjang batas (Gambar 3) ditunjukkan oleh Tabel 2. Terlihat jelas dari tabel tersebut bahwa kondisi gelombang lepas pantai didominasi oleh swell dari barat dan barat daya ( 190-230 derajat) dengan periode 12-14 detik.

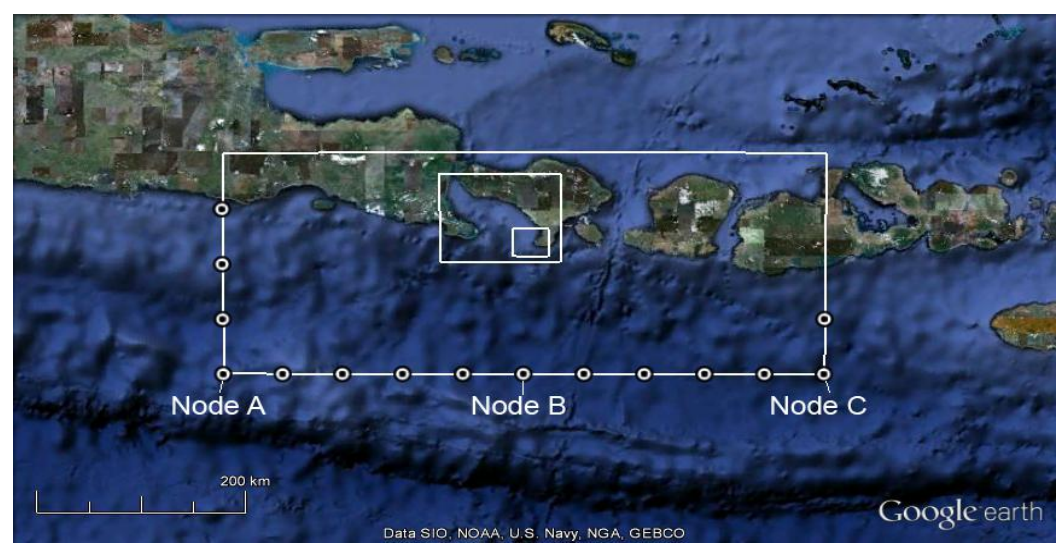

Gambar 3.Node yang digunakan untuk kondisi gelombang pada grid model \#1, statistik gelombang untuk node $\mathrm{A}$, node $\mathrm{B}$ dan node $\mathrm{C}$ disajikan pada Tabel 1 di bawah ini.

Tabel 2. Joint Probability dari Tinggi Gelombang Signifikan, Periode Puncak Gelombang dan Arahnya yang Terjadi Selama 14 Tahun untuk Node A, Node B dan Node C.

\begin{tabular}{cccccccccccrcr}
\hline \multicolumn{3}{c}{ Node A: 10S, 112.5E } & \multicolumn{4}{c}{ Node B: 10S, 115E } & \multicolumn{3}{c}{ Node C: 10S, 117.5E } \\
$\begin{array}{c}\text { Occur. } \\
\text { \% }\end{array}$ & $\begin{array}{c}\boldsymbol{H}_{\boldsymbol{S}} \\
{[\mathbf{m}]}\end{array}$ & $\begin{array}{c}\boldsymbol{T}_{\boldsymbol{p}} \\
{[\mathbf{s}]}\end{array}$ & $\begin{array}{c}\boldsymbol{D}_{\boldsymbol{p}} \\
{[\mathbf{d e g}]}\end{array}$ & $\begin{array}{c}\text { Occur. } \\
\mathbf{\%}\end{array}$ & $\begin{array}{c}\boldsymbol{H}_{\boldsymbol{S}} \\
{[\mathbf{m}]}\end{array}$ & $\begin{array}{c}\boldsymbol{T}_{\boldsymbol{p}} \\
{[\mathbf{s}]}\end{array}$ & $\begin{array}{c}\boldsymbol{D}_{\boldsymbol{p}} \\
{[\mathbf{d e g}]}\end{array}$ & $\begin{array}{c}\text { Occur. } \\
\boldsymbol{\%}\end{array}$ & $\begin{array}{c}\boldsymbol{H}_{\boldsymbol{S}} \\
{[\mathbf{m}]}\end{array}$ & $\begin{array}{c}\boldsymbol{T}_{\boldsymbol{p}} \\
{[\mathbf{s}]}\end{array}$ & $\begin{array}{c}\boldsymbol{D}_{\boldsymbol{p}} \\
\text { [deg] }\end{array}$ \\
\hline 22.8 & 2.25 & 13.3 & 210 & 24.5 & 2.25 & 13.4 & 210 & 25.6 & 1.75 & 13.0 & 210 \\
\hline 19.5 & 1.75 & 12.8 & 210 & 22.3 & 1.75 & 12.8 & 210 & 21.3 & 2.25 & 13.8 & 210 \\
\hline 15.2 & 2.75 & 14.1 & 210 & 14.8 & 2.75 & 14.2 & 210 & 13.9 & 1.25 & 12.3 & 210 \\
\hline 6.3 & 1.25 & 12.1 & 210 & 8.5 & 1.25 & 12.1 & 210 & 9.1 & 2.75 & 14.6 & 210 \\
\hline 6.2 & 3.25 & 14.7 & 210 & 5.9 & 1.75 & 13.9 & 230 & 8.2 & 1.75 & 13.8 & 230 \\
\hline 5.1 & 2.25 & 14.3 & 230 & 5.3 & 3.25 & 14.9 & 210 & 5.7 & 2.25 & 14.6 & 230 \\
\hline 5.1 & 1.75 & 13.9 & 230 & 5.1 & 2.25 & 14.3 & 230 & 4.7 & 1.25 & 13.5 & 230 \\
\hline 3.0 & 2.25 & 12.9 & 190 & 2.7 & 2.75 & 15.1 & 230 & 2.7 & 3.25 & 15.2 & 210 \\
\hline 2.5 & 3.75 & 15.4 & 210 & 2.1 & 1.25 & 13.3 & 230 & 2.3 & 2.75 & 14.9 & 230 \\
\hline
\end{tabular}


Untuk simulasi gelombang angin, data angin dari empat titik di bagian barat dan timur sepanjang grid terluar diinterpolasi untuk grid daerah angin pemodelan SWAN selama tahun 2010.

\section{DATA DAN VALIDASI}

\subsection{Data Hindcast Gelombang}

Untuk mengetahui transformasi gelombang dari lepas pantai menuju pantai, dilakukan hindcast gelombang jangka panjang. Data hindcast gelombang didapatkan dari output model WAVEWATCH III. Model WAVEWATCH III merupakan model global gelombang yang dikembangkan oleh Marine Modelling and Analysis Branch (MMAB) pada Environmental Modelling Center (EMC) National Centers for Environmental Prediction (NCEP) dan dapat diakses secara online melalui http://polar.ncep.noaa.gov/waves. Input angin pada model ini berasal dari Global Forecast System (GFS) NCEP, yaitu kecepatan angin pada ketinggian $10 \mathrm{~m}$, dengan resolusi $1 / 2$ derajat, dan interval waktu 1 jam.

Data gelombang diekstrak pada node yang terletak di $9^{\circ} \mathrm{S} 115^{\circ} \mathrm{E}$ dengan kedalaman 1.500 m (Gambar 5.a) pada bulan Februari 1997 sampai dengan bulan Juli 2011 sebagai kuantifikasi awal statistik gelombang di lepas pantai. Selain itu, data gelombang dari beberapa node output model juga diekstrak untuk kemudian digunakan sebagai kondisi batas (boundary conditions) pada pemodelan transformasi gelombang dengan SWAN model. Time-series dari tinggi gelombang signifikan, periode puncak gelombang dan arah gelombang ditunjukan pada Gambar 5.b, sedangkan hasil statistik gelombang untuk jangka waktu 14 tahun 5 bulan ditunjukan pada Tabel 3. Variasi musiman untuk kondisi gelombang dapat terlihat pada hasil dekomposisi bulanannya (Tabel 4).

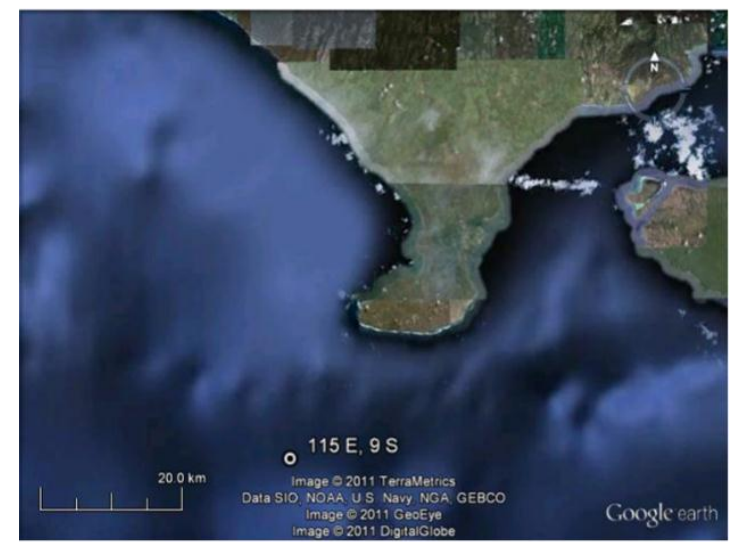

(a)
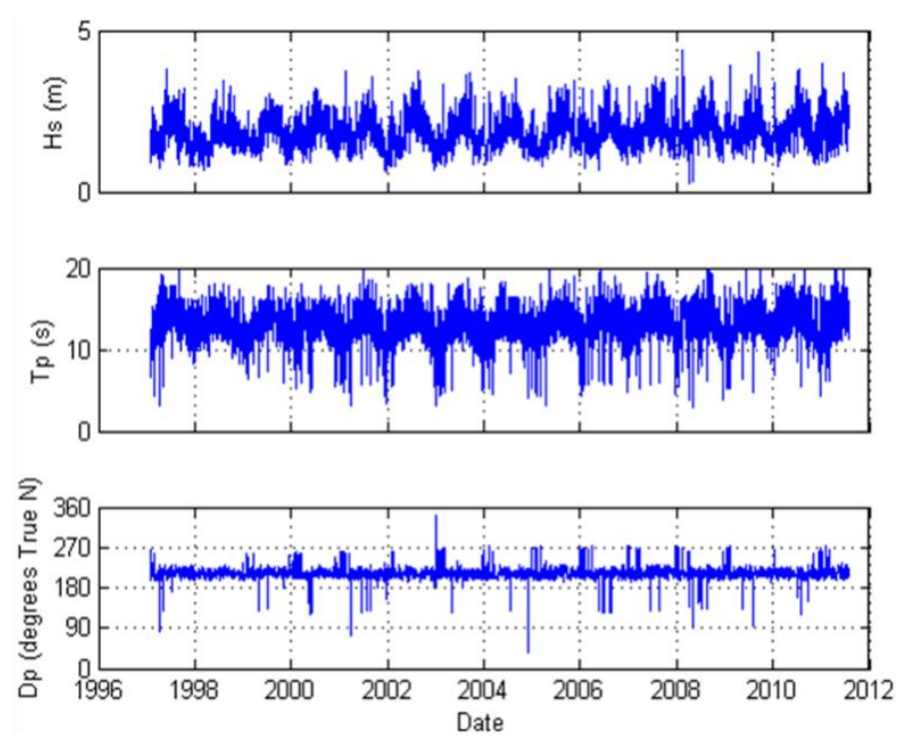

(b)

Gambar 5. (a) Lokasi node output model WW3; (b) Tíme-series dari tinggi gelombang signifikan, periode puncak gelombang dan arah gelombang di node output WW3. 
Tabel 3. Statistik Gelombang Output Model WW3 selama 14 Tahun 5 Bulan (Feb 1997 hingga Jul 2011) untuk Node di $9^{\circ} \mathrm{LS} 115^{\circ} \mathrm{BT}$.

\begin{tabular}{ccccc} 
Node & $\begin{array}{c}\mathrm{H}_{S} \text { Mean } \\
{[\mathrm{m}]}\end{array}$ & $\begin{array}{c}\mathrm{H}_{\boldsymbol{S}} \text { Max } \\
{[\mathrm{m}]}\end{array}$ & $\begin{array}{c}\mathrm{T}_{\boldsymbol{p}} \text { Mean } \\
{[\mathrm{s}]}\end{array}$ & $\begin{array}{c}\text { Dir Mean } \\
{\left[{ }^{\circ}\right]}\end{array}$ \\
\hline $\mathbf{9}^{\circ} \mathbf{S} \mathbf{1 1 5}{ }^{\circ} \mathrm{E}$ & 1.84 & 4.37 & 12.8 & 213 \\
\hline
\end{tabular}

Tabel 4. Dekomposisi Bulanan Statistik Gelombang (Feb 1997 sampai Juli 2011) untuk Node di $9^{\circ}$ LS $115^{\circ}$ BT.

\begin{tabular}{ccccc}
\hline Month & $\begin{array}{c}\boldsymbol{H}_{\boldsymbol{S}} \text { Mean } \\
{[\mathbf{m}]}\end{array}$ & $\begin{array}{c}\boldsymbol{H}_{\boldsymbol{S}} \text { Max } \\
{[\mathrm{m}]}\end{array}$ & $\begin{array}{c}\boldsymbol{T}_{\boldsymbol{p}} \text { Mean } \\
{[\mathbf{s}]}\end{array}$ & $\begin{array}{c}\text { Dir Mean } \\
{\left[{ }^{\circ}\right]}\end{array}$ \\
\hline Jan & 1.70 & 4.00 & 11.4 & 216 \\
\hline Feb & 1.72 & 4.37 & 11.3 & 218 \\
\hline Mar & 1.57 & 2.87 & 12.3 & 213 \\
\hline Apr & 1.59 & 3.12 & 12.9 & 210 \\
\hline May & 1.86 & 3.26 & 13.4 & 210 \\
\hline Jun & 2.08 & 3.77 & 13.7 & 213 \\
\hline Jul & 2.23 & 3.79 & 13.8 & 213 \\
\hline Aug & 2.16 & 3.72 & 13.7 & 212 \\
\hline Sep & 2.17 & 4.30 & 13.7 & 212 \\
\hline Oct & 1.85 & 3.29 & 12.9 & 212 \\
\hline Nov & 1.57 & 3.43 & 12.4 & 213 \\
\hline Dec & 1.54 & 3.03 & 11.4 & 215 \\
\hline
\end{tabular}

Terlihat jelas dari Tabel 4 di atas bahwa kondisi gelombang lepas pantai didominasi oleh gelombang dengan periode 11.4-13.8 detik yang berasal dari barat daya ( 210-218 derajat).

\subsection{Data Angin Jangka Panjang}

Data angin pada bulan Februari 1997 sampai dengan Juli 2011 diekstrak pada lokasi yang sama dengan yang telah disebutkan sebelumnya.
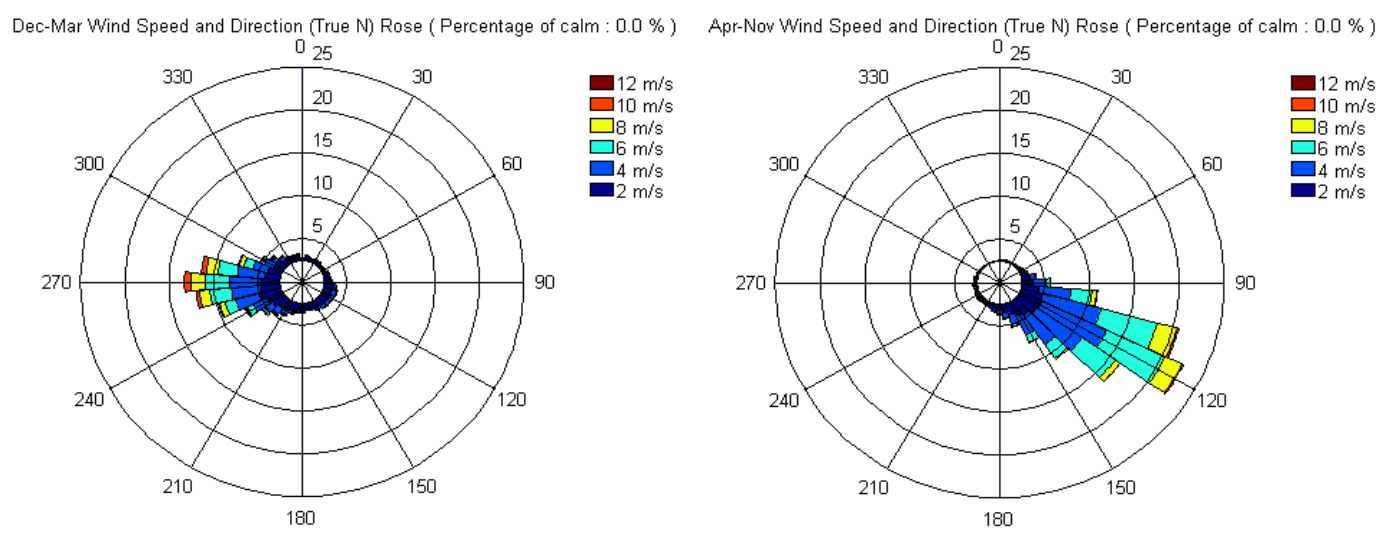

Gambar 6. Windrose untuk node di $9^{\circ}$ LS $115^{\circ} \mathrm{BT}$ (Feb 1997 - Jul 2011) saat musim basah (Desember-Maret) dan musim kering (April-November). 
Hasil dekomposisi bulanan untuk kecepatan dan arah angin menunjukan adanya variasi musiman. Variasi musiman tersebut dapat dilihat pada windrose musiman (Gambar 6) dimana data pada bulan Desember hingga Maret termasuk ke dalam musim barat dan untuk musim tenggara direpresentasikan oleh data pada bulan April hingga November. Angin musim barat memiliki periode waktu yang lebih pendek dibandingkan saat angin musim tenggara (4 bulan banding 8 bulan). Kecepatan angin saat musim barat lebih tinggi, yaitu mencapai lebih dari $10 \mathrm{~m} / \mathrm{s}$ atau 36 $\mathrm{km} / \mathrm{jam}$, dibandingkan kecepatan angin saat musim tenggara, yang umumnya tidak melebihi $8 \mathrm{~m} / \mathrm{s}(29 \mathrm{~km} / \mathrm{jam})$.

\section{VALIDASI HASIL MODEL}

Hasil model gelombang swell, dikalibrasi dengan data pengukuran di lapangan yang berlokasi $800 \mathrm{~m}$ dari Pantai Dreamland, pada kedalaman $12.5 \mathrm{~m}$, seperti pada Gambar 7.a. Data pengukuran gelombang diperoleh dari PT. ASR (2012). Pengukuran dan perekaman data dilakukan pada 18 Desember 2011 sampai dengan 11 Februari 2012. Grafik perbandingan hasil model dengan data pengukuran terlihat pada Gambar 7.b.

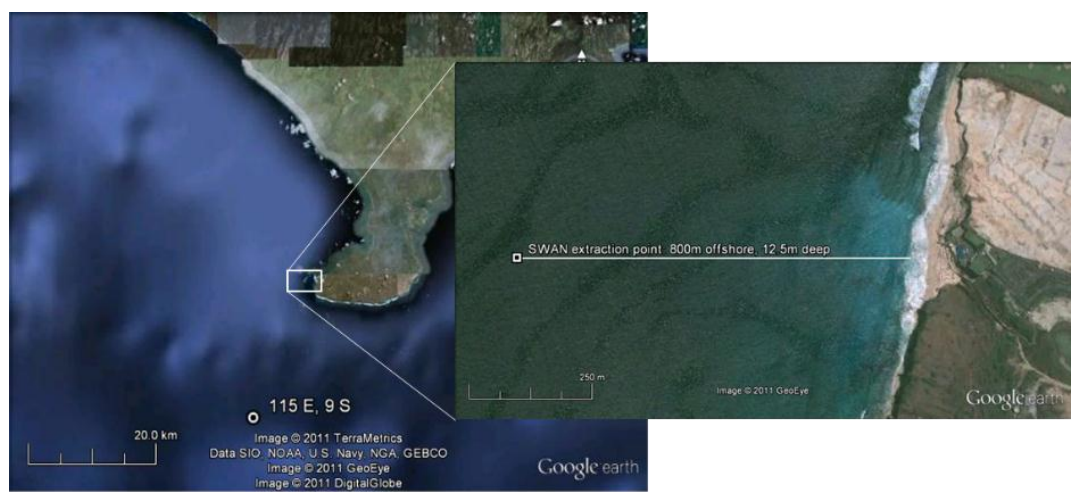

(a)

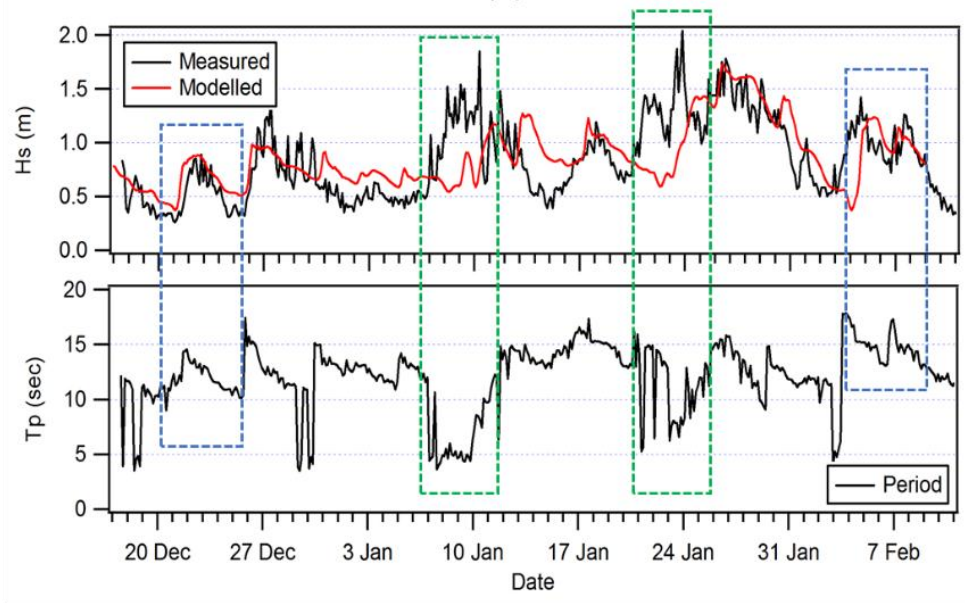

(b)

Gambar 7. (a) Lokasi pengambilan data lapangan; (b) Perbandingan tinggi gelombang signifikan dan periode puncak gelombang hasil model gelombang swelldengan data pengamatan. 
Dari grafik pada Gambar $\mathbf{7}$ tersebut terlihat ketika periode gelombangnya kecil (mengindikasikan gelombang angin terbentuk oleh sistem iklim lokal) model secara umum memperlihatkan ketidaksesuaian dengan data hasil pengukuran (ditandai dengan garis putus-putus berwarna hijau). Namun ketika periode gelombangnya besar (12-15 detik) dan angin lokal bertiup dengan kecepatan kecil, hasil model dan data pengukuran menunjukan kesesuaian yang cukup baik (ditandai dengan garis putus-putus berwarna biru).

Namun perlu dicatat, tinggi gelombang signifikan hasil pengamatan, merupakan nilai rata-rata hasil statistik gelombang. Dengan demikian, nilai tersebut merupakan gabungan dari berbagai sumber energi gelombang. Maka, pengaruh gelombang angin perlu ditambahkan pada komponen gelombang swel/ hasil model ketika arah gelombang kurang dari $265^{\circ}$ seperti pada Persamaan 4. Pemilihan bobot gelombang angin yang kurang dari $265^{\circ}$ tersebut dilakukan dengan alasan karena umumnya arah dominan gelombang angin pada lokasi pengamatan lebih banyak dari barat dan barat daya.

$$
H_{S}=H_{S<\text { swell }}+H_{S<\text { wind }} \text { if Dir }<265^{\circ}
$$

Gambar 8 menunjukan perbandingan tinggi gelombang signifikan, periode puncak gelombang dan arah gelombang, antara data pengamatan dan hasil model. Kesesuaian antara data pengamatan dan hasil model dapat terlihat setelah dilakukan pengolahan data dengan mempertimbangkan pengaruh angin lokal.

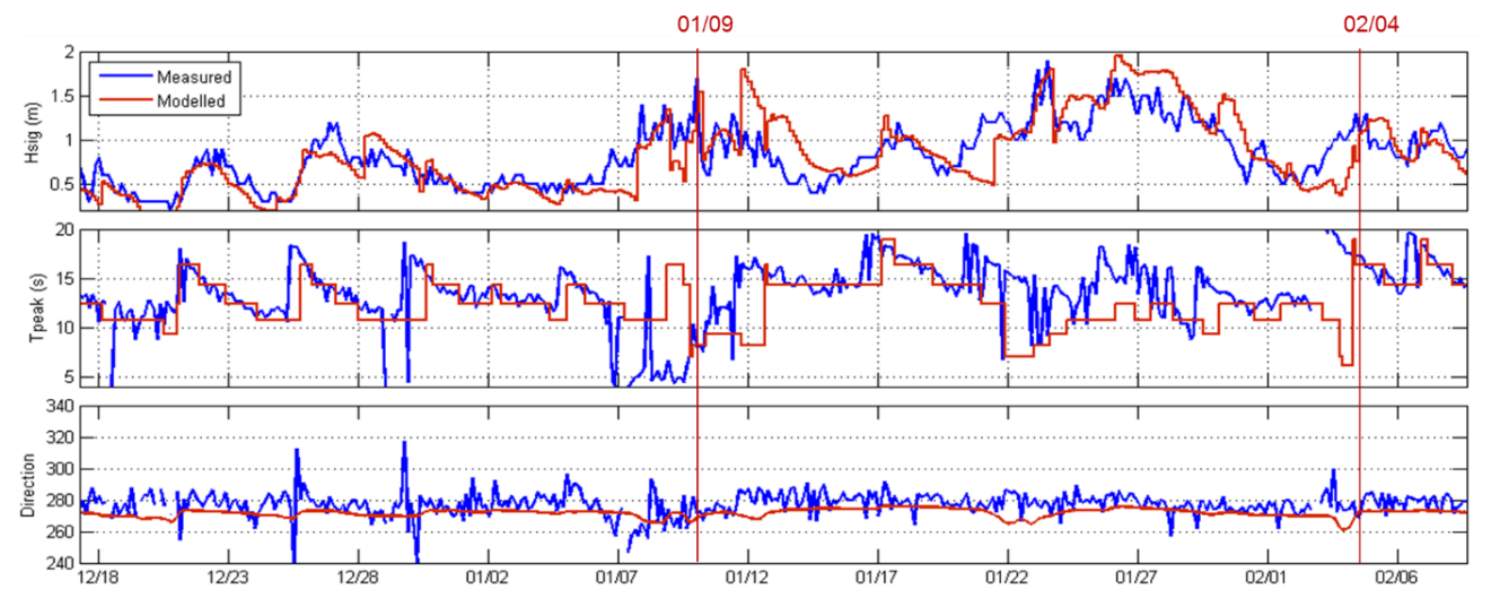

Gambar 8. Perbandingan tinggi gelombang signifikan, periode puncak dan arah gelombang hasil model gelombang swell yang telah mendapat pengaruh angin lokal dengan data pengamatan.

\section{HASIL DAN PEMBAHASAN}

Gambar 9 dan Gambar 10 merupakan hasil simulasi skema awal pemodelan pada nested grid $\# 1$, yaitu simulasi gelombang swell saat musim kering, dan simulasi gelombang angin saat musim basah; dimana musim kering diwakili oleh simulasi pada bulan Mei, sedangkan musim basah diwakili oleh bulan Desember. Terlihat bahwa gelombang mengalami transformasi, baik tinggi maupun arahnya saat 
menjalar dari lepas pantai menuju ke pantai. Tinggi gelombang semakin berkurang dan arah gelombang mengalami pembelokan.

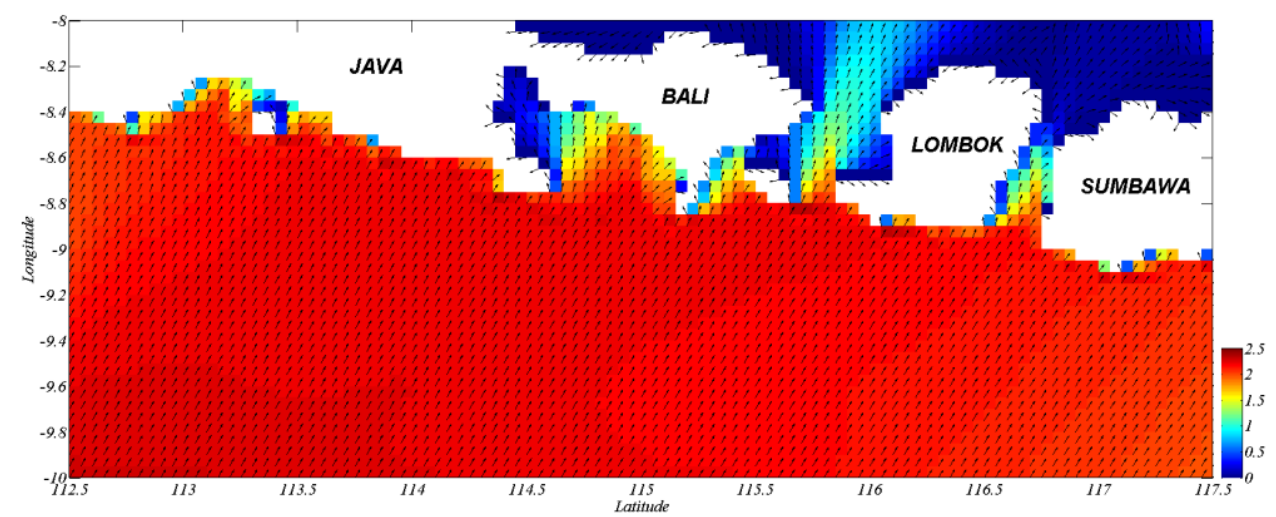

Gambar 9. Tinggi gelombang signifikan (dalam $\mathbf{m}$ ) dan arah gelombang pada tanggal 20 Mei 2010 untuk grid \#1.

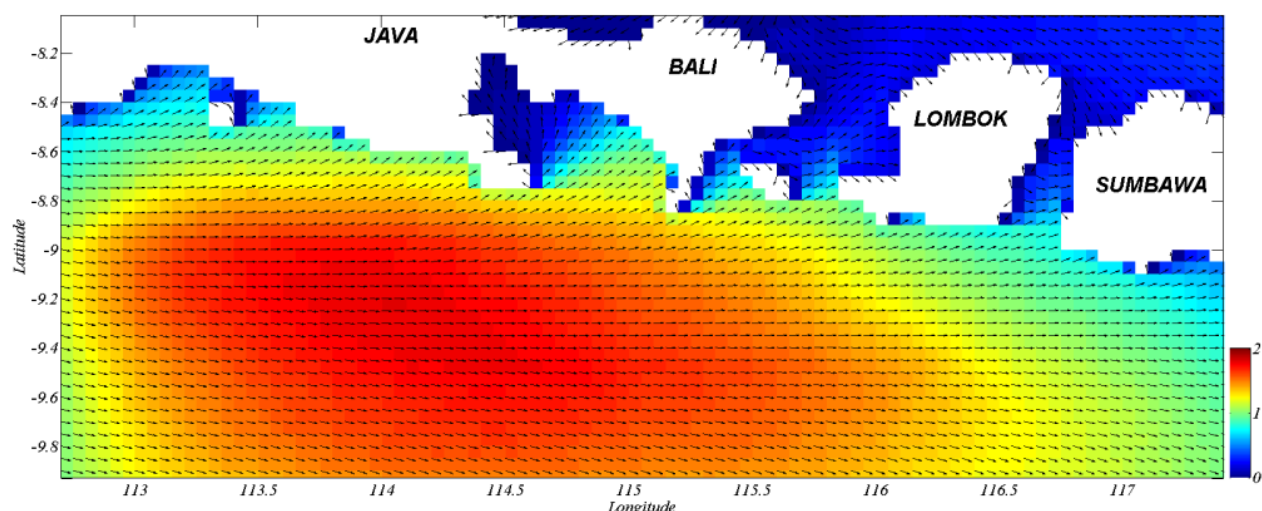

Gambar 10.Tinggi gelombang signifikan (dalam $\mathbf{m}$ ) dan arah gelombang pada tanggal 18 Desember 2010 untuk grid \#1.

Simulasi kemudian difokuskan pada dua kejadian gelombang saat pengukuran lapangan dilakukan. Pada Gambar 8, dapat diketahui bahwa pada tanggal 9 Januari 2012 terlihat adanya gelombang tinggi namun periode gelombangnya pendek. Hal ini mengindikasikan bahwa saat itu terjadi gelombang badai atau gelombang angin. Gelombang swel/ dengan periode panjang terjadi pada tanggal 4 Februari 2012. Hasil model nested grid untuk dua kejadian tersebut dapat dilihat pada Gambar 11, Gambar 12, dan Gambar 13 berikut:
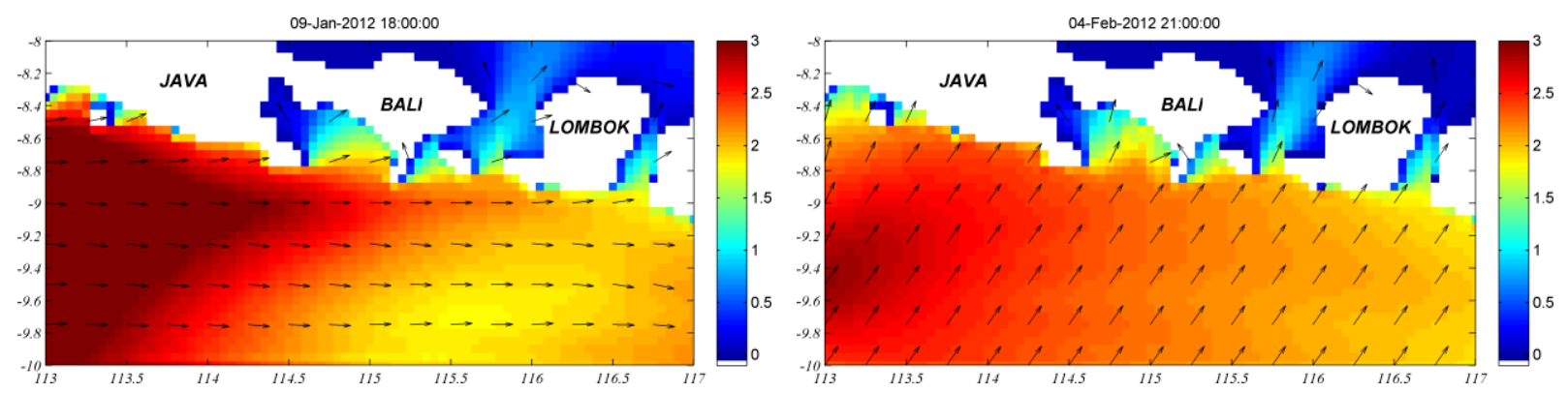

Gambar 11. Kejadian saat terjadinya gelombang angin pada 9 Januari (kiri) dan kejadian saat terjadinya gelombang swell pada 4 Februari (kanan) pada grid \#1. 

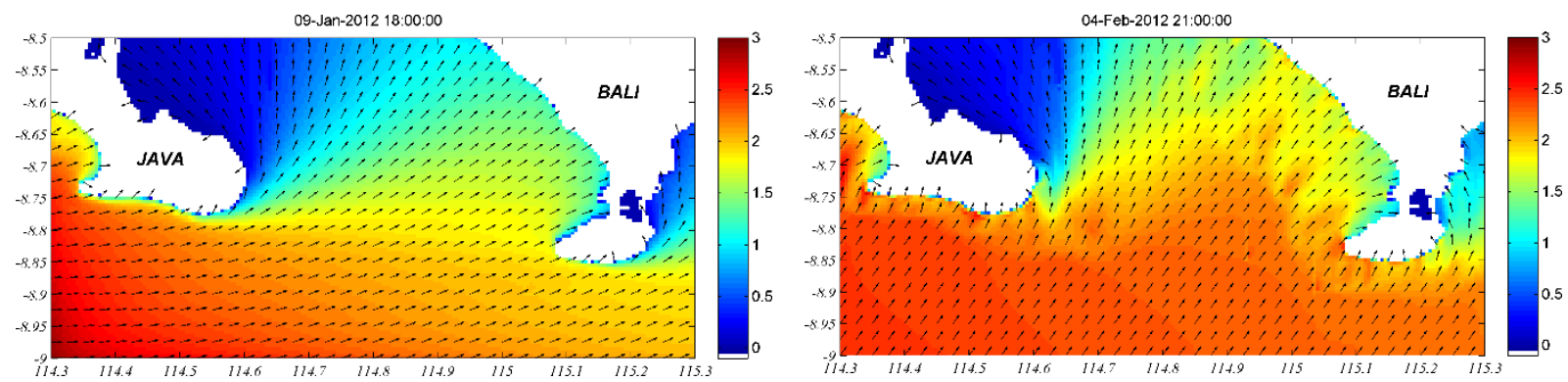

Gambar 12. Kejadian saat terjadinya gelombang angin pada 9 Januari (kiri) dan kejadian saat terjadinya gelombang swell pada 4 Februari (kanan) pada grid \#2.
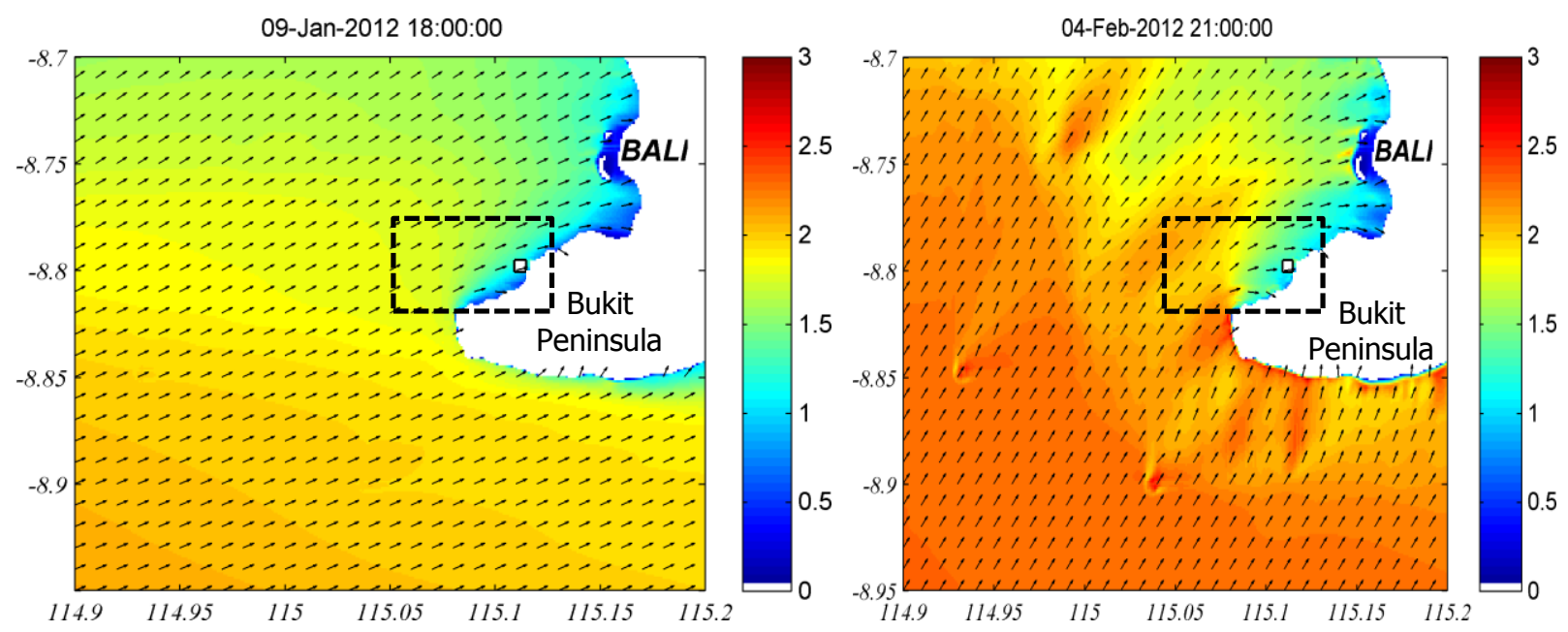

Gambar 13. Kejadian saat terjadinya gelombang angin pada 9 Januari (kiri) dan kejadian saat terjadinya gelombang swell pada 4 Februari (kanan) pada grid \#3.
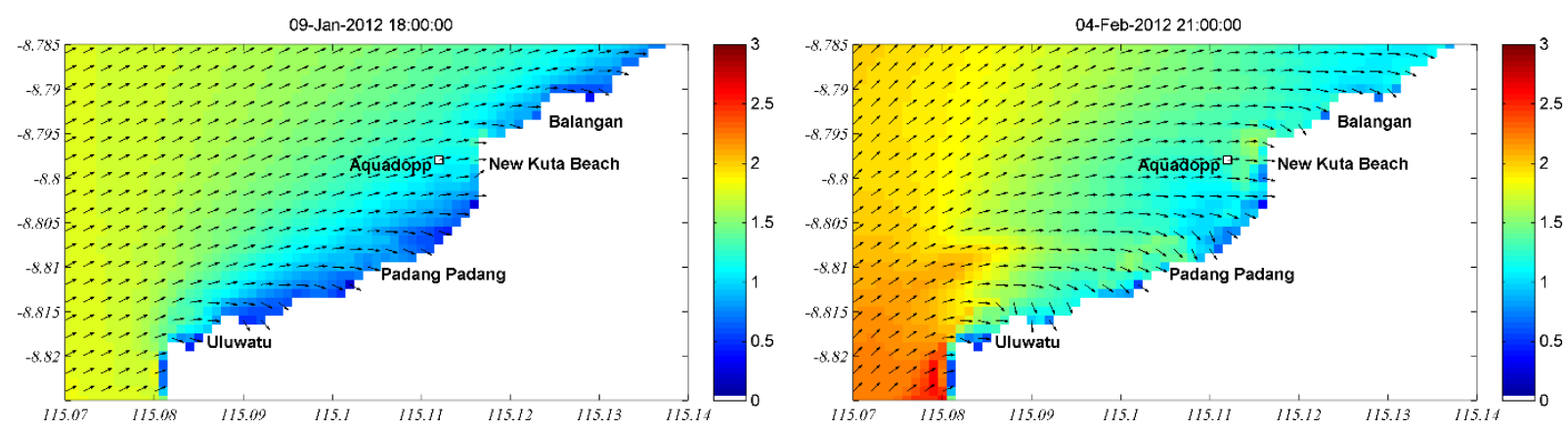

Gambar 14. Gambar yang diperbesar dari kejadian saat terjadinya gelombang angin pada 9 Januari (kiri) dan kejadian saat terjadinya gelombang swell tanggal 4 Februari (kanan).

Dari hasil simulasi pada Gambar 9 s.d. Gambar 14 di atas terlihat jelas adanya penurunan tinggi gelombang dan perubahan arah gelombang dari lepas pantai menuju ke pantai. Tinggi gelombang di lepas pantai terutama di bagian terluar batas model, mencapai lebih dari $2 \mathrm{~m}$. Tinggi gelombang ini kemudian berkurang hingga mencapai sekitar $1 \mathrm{~m}$ di area dekat pantai. Hal ini terjadi baik pada saat kejadian gelombang angin maupun saat terjadinya gelombang swell. Namun saat terjadi gelombang angin dimana angin dominan bertiup dari arah barat dan barat daya, tinggi gelombang yang dihasilkan lebih rendah bila dibandingkan dengan saat 
terjadinya gelombang swell. Pada saat menuju pantai, gelombang juga mengalami refraksi.

Pada Gambar 12, terlihat bahwa gelombang swell dengan periode panjang saat mencapai pantai mengalami refraksi yang lebih besar ke arah selatan dibandingkan dengan gelombang angin. Gelombang angin yang semula arahnya dari barat dibelokan sehingga saat mencapai pantai lokasi pengamatan, arahnya menjadi tegak lurus pantai. Sedangkan gelombang swell yang semula arahnya dari barat daya, mengalami refraksi yang lebih kuat di sekitar Bukit Peninsula, sehingga gelombang terefraksi ke arah selatan.

\section{KESIMPULAN}

Berdasarkan hasil analisis yang telah dilakukan, maka dapat disimpulkan bahwa selain dipengaruhi oleh gelombang angin, gelombang swell juga memberikan pengaruh yang besar terhadap kondisi gelombang di perairan selatan Bali. Gelombang swell yang berasal dari Samudera Hindia menjalar dari arah barat daya memasuki perairan selatan Bali dan kemudian mengalami refraksi yang kuat di sekitar Bukit Peninsula. Dibandingkan dengan gelombang angin, gelombang swell menghasilkan tinggi gelombang yang lebih besar baik saat di lepas pantai maupun di area dekat pantai. Tingginya gelombang swel/ ini berpotensi merusak struktur pantai dan mengganggu aktivitas yang terjadi di pantai jika terjadi superposisi dengan gelombang pasang-surut terutama saat terjadi pasang purnama. Karenanya perlu dilakukan kajian lebih lanjut dengan mempertimbangkan juga kondisi gelombang pasang surut.

\section{DAFTAR RUJUKAN}

ASR, PT. Pengumpulan Data Lapangan dan Pemodelan Numerik Hidrodinamika, Stabilisasi, Pantai New Kuta Beach. Laporan intern perusahaan, tidak dipublikasikan. Jakarta: PT. ASR.

Booij, N. R. R. C., Ris, R. C. \& Holthuisjen, L. H. (1999). A third-generation wave model for coastal regions: 1 . Model description and validation. Journal of geophysical research: Oceans, 104 (C4), 7649-7666.

Choi, B. H., Eum, H. M. \& Woo, S. B. (2003). Modeling of coupled tide-wave-surge process in the Yellow Sea. Ocean Engineering, 30 (6), 739-759.

Habibie, M. N. \& Permana, D., S. (2013). SIMULASI GELOMBANG EKSTRIM AKIBAT SWELL DI INDONESIA MENGGUNAKAN MODEL WAVEWATCH-III. Jurnal Meteorologi dan Geofisika , 14(2), 98-108.

Mettlach, T., Wang, D. \& Wittmann, P. (1994). Analysis and prediction of ocean swell using instrumented buoys. Atmospheric and Oceanic Technology, 11 (2), 506-524.

Nugraheni, I. R., Wijayanti, D. P., Sugianto, D., N. \& Ramdhani, A. (2017, February). Study of inundation events along the southern coast of Java and Bali, Indonesia (case studies 49 June 2016). In _ (Ed.), IOP Conference Series: Earth and Enviromental Science. 55 No 1, pp. 012-014. IOP Publishing.

Tolman, H., L. (2009). User manual and system documentation of WAVEWATCH III version 3.14. Technical Report. NOAA/NWS/NCEP/MMAB.

Young, I. R. (1999). Wind generated ocean waves. Kidlington, Oxford: Elsevier Science, Ltd. 